\author{
Marcin Salamaga \\ Katedra Statystyki \\ Uniwersytet Ekonomiczny w Krakowie
}

\title{
Propozycja modyfikacji wskaźnika ujawnionej przewagi komparatywnej z wykorzystaniem funkcji wymiernych
}

\section{Streszczenie}

Wskaźnik względnej przewagi komparatywnej $(R C A)$ jest wykorzystywany powszechnie do oceny konkurencyjności eksportu towarów i usług oraz przewagi komparatywnej kraju według sektorów produkcji lub grup towarowych. Jego wartości nie są jednak unormowane, co skutkuje określonymi konsekwencjami. Rozkłady wskaźnika $R C A$ są zwykle asymetryczne, niestabilne w czasie, wrażliwe na liczbę sektorów (grup towarowych) i na liczbę krajów w grupie referencyjnej. Utrudnia to porównywalność wartości wskaźnika w ujęciu czasowym i przestrzennym oraz komplikuje wyznaczenie odpowiedniego rozkładu teoretycznego. W artykule zaproponowano pewną metodę transformacji wskaźnika $R C A$, która umożliwia poprawę niektórych jego własności. Proponowana metoda wykorzystuje transformację przedmiotowego wskaźnika za pomocą rodziny funkcji wymiernych. W pracy analizowano empiryczne rozkłady unormowanego wskaźnika $R C A$ dla towarów grupowanych zgodnie ze standardową międzynarodową klasyfikacją handlu (SITC).

Słowa kluczowe: wskaźnik względnej przewagi komparatywnej, eksport, rozkład stabilny, test chi-kwadrat. 


\section{Wprowadzenie}

W badaniach nad konkurencyjnością eksportu towarów i usług oraz przewag komparatywnych kraju według sektorów produkcji bądź grup towarowych bardzo często wykorzystuje się wskaźnik względnej przewagi komparatywnej $(R C A)$ zaproponowany przez B. Balassę [1965]. Wskaźnik ten jest zdefiniowany jako stosunek wartości eksportu badanej grupy towarowej analizowanego kraju w całkowitej wartości eksportu kraju do udziału wartości światowego eksportu wyróżnionej grupy towarów w całkowitej wartości światowego eksportu. Miernik Balassy powstał w ramach nurtu badań nad międzynarodowym konkurowaniem gospodarek, który został zainspirowany zasadą kosztów względnych D. Ricardo [1957]. Obecnie w licznych analizach stosuje się również reinterpretacje oryginalnej formuły Balassy, np. zastępując całkowitą wartość eksportu przez wartość importu odpowiednich towarów [Misala 2011].

Wskaźnik względnej przewagi komparatywnej cechuje się niewielką uciążliwością obliczeniową i łatwą interpretacją wyników. Ma on jednak kilka wad wynikających m.in. z braku unormowania jego wartości.

Empiryczne rozkłady sektorowego wskaźnika $R C A$ cechują się na ogół silną asymetrią i brakiem stabilności w czasie, co w istotny sposób ogranicza porównywalność jego wartości w ujęciu czasowym i przestrzennym. Za kolejną wadę należy uznać to, że wartości wskaźnika są wrażliwe zarówno na liczbę sektorów (grup towarowych), jak i na liczbę krajów w grupie referencyjnej. Skutkuje to brakiem stabilności ważnych charakterystyk liczbowych miernika i stanowi utrudnienie przy wyznaczeniu teoretycznego rozkładu jego wartości. W literaturze przedmiotu podejmowane są próby konstrukcji unormowanych wskaźników względnej przewagi komparatywnej, np. addytywny wskaźnik RCA [Hoen i Oosterhaven 2006], znormalizowany indeks względnej przewagi komparatywnej [Yu, Cai i Leung 2000], wskaźnik względnej symetrycznej przewagi komparatywnej [Dalum, Laursen i Villumsen 1998] oraz [Iapadre 2001]. Nie zyskały one jednak do tej pory trwałej popularności w empirycznych zastosowaniach wśród badaczy międzynarodowej wymiany handlowej.

W opracowaniu zaproponowano metodę transformacji wskaźnika $R C A$ o wartościach z przedziału $[0 ; \infty)$ do przedziału liczbowego od -1 do 1 . Zastosowano do tego celu pewną rodzinę funkcji wymiernych. Proponowane przekształcenie powinno poprawić niektóre własności miernika względnej przewagi komparatywnej. Empiryczne rozkłady zmodyfikowanego wskaźnika $R C A$ badano na podstawie danych o międzynarodowej wymianie handlowej Polski. W obliczeniach wykorzystano dane Eurostatu z lat 2005-2009. 


\section{Konstrukcja skorygowanego wskaźnika ujawnionej przewagi komparatywnej}

Podstawą konstrukcji skorygowanego miernika względnej przewagi komparatywnej jest wskaźnik Balassy [1965], który można wyrazić następującą formułą:

$$
R C A_{i}=\frac{X_{i j}}{X_{j}}: \frac{X_{i}}{X},
$$

gdzie:

$X_{i j}$-wartość eksportu $i$-tej grupy towarowej w $j$-tym kraju,

$X_{j}$ - całkowita wartość eksportu $j$-tego kraju,

$X_{i}$ - wartość światowego eksportu $i$-tej grupy towarowej,

$X$ - całkowita wartość eksportu światowego.

Wartości wskaźnika (1) większe od jedności wskazują na występowanie przewagi komparatywnej, a także określają jej intensywność. Wartości mniejsze od 1 wskazują na brak tego typu przewagi. Miernik (1) jest również stosowany w sytuacji oceny konkurencyjności eksportu kraju w porównaniu z krajami referencyjnymi (np. krajami regionu geograficznego, ugrupowaniem gospodarczym czy krajem partnerskim). Odpowiednia formuła ma wówczas postać:

gdzie:

$$
R C A_{i}=\frac{X_{i j}}{X_{j}}: \frac{X_{i}^{R}}{X^{R}},
$$

$X_{i j}$ - wartość eksportu $i$-tej grupy towarowej w $j$-tym kraju,

$X_{j}$ - całkowita wartość eksportu j-tego kraju,

$X_{i}^{R}$ - wartość światowego eksportu $i$-tej grupy towarowej w krajach referencyjnych,

$X^{R}$ - całkowita wartość eksportu światowego w krajach referencyjnych.

Fakt, że wskaźnik względnej przewagi komparatywnej nie jest unormowany, powoduje, iż jego rozkłady empiryczne zazwyczaj cechują się asymetrią i brakiem stabilności w ujęciu czasowym i przestrzennym. Może to sprawiać pewne trudności w porównywaniu rozkładów wskaźnika $R C A$ obliczanego np. dla różnych grup towarowych.

W artykule proponuje się przekształcenie wskaźnika $R C A$, które poprawia niektóre z jego własności. Przekształcenie polega na wykorzystaniu klasy funkcji wymiernych o następującej postaci:

$$
f(x)=\frac{x^{a}-1}{x^{a}+1},
$$

gdzie $a$ to dowolna liczba dodatnia. 
Proponowany skorygowany wskaźnik względnej przewagi komparatywnej ma więc postać:

$$
R C A_{k}^{a}=\frac{R C A^{a}-1}{R C A^{a}+1} .
$$

Konstrukcja wskaźnika (4) jest inspirowana miarą zaproponowaną przez B. Daluma, K. Laursena i G. Villumsena [1998] i stanowi jej uogólnienie. Przekształcenie (3) pozwala uzyskać unormowaną wartość wskaźnika $R C A_{k}^{a}$ w przedziale od -1 do 1 . Dodatnie wartości wskaźnika (4) wskazują na występowanie ujawnionej przewagi komparatywnej w eksporcie, zaś ujemne wartości tego miernika wskazują na brak takiej przewagi. Od przyjętej wartości parametru $a$ zależy tempo zbieżności wskaźnika $R C A_{k}^{a}$ do wartości granicznych przedziału $[-1 ; 1)$. Na rys. 1 przedstawiono przebieg wartości miernika $R C A_{k}^{a} \mathrm{w}$ zależności od wartości oryginalnego wskaźnika $R C A$ dla wybranych poziomów parametru $a$.

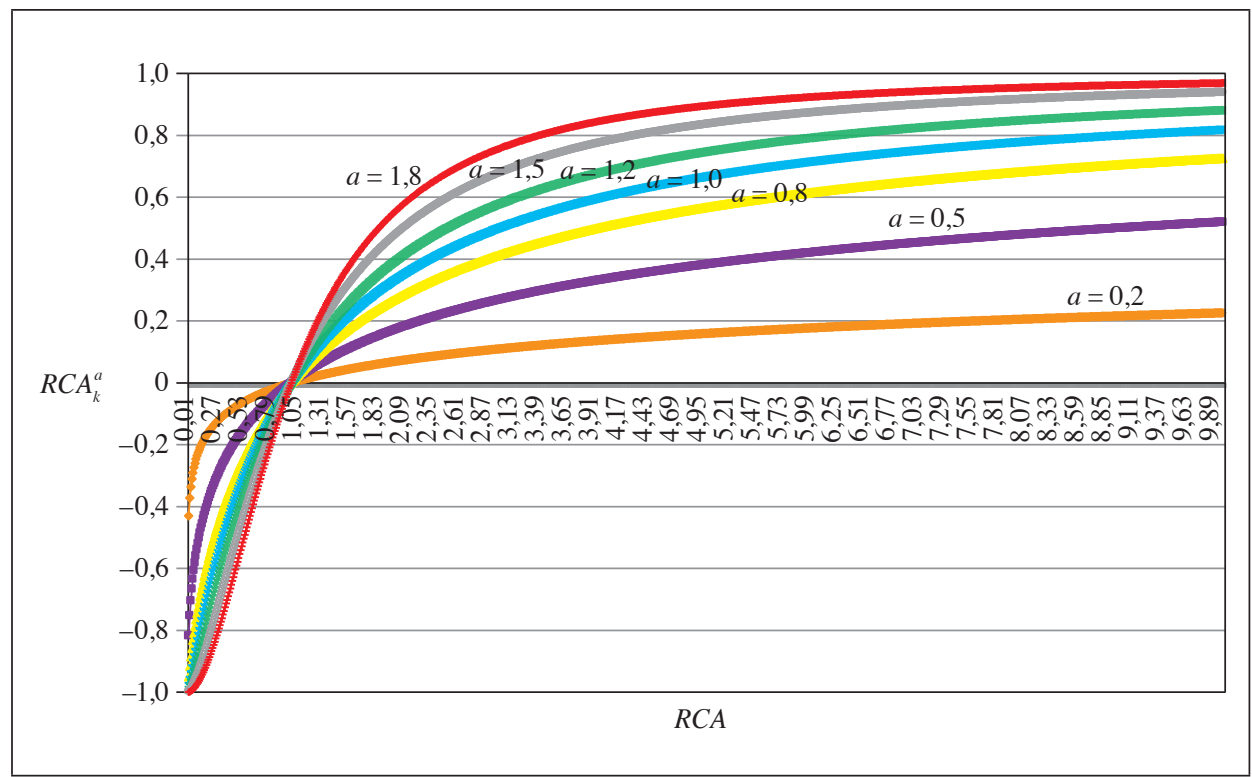

Rys. 1. Przebieg wartości wskaźnika $R C A_{k}^{a}$ w zależności od wskaźnika $R C A$ dla wybranych wartości parametru $a$ Źródło: opracowanie własne.

Im wyższy jest poziom parametru $a$, tym intensywniej wartości miernika $R C A_{k}^{a}$ zmierzają do wartości granicznych przedziału zmodyfikowanego wskaźnika. Natomiast im poziom parametru $a$ jest bliższy 0 , tym wolniej wartości miernika $R C A_{k}^{a}$ zmierzają do dolnej i górnej granicy przedziału $[-1 ; 1)$. W praktyce 
wybór wartości parametru $a$ decyduje, jakie będą rzeczywiste wartości ekstremalne przekształconego wskaźnika $R C A$ oraz jakie jest tempo jego „zbliżania się” do wartości granicznych równych odpowiednio -1 i 1.

Przyjmijmy przykładowo, że liczba $\pm 0,99$ jest granicą „dostatecznej bliskości” dla $1 \mathrm{i}-1$. Wówczas wymaganą wartość parametru $a$ gwarantującą spełnienie warunku $\left|R C A_{k}^{a}\right|>0,99$ w zależności od maksymalnej wartości wskaźnika $R C A$ można opisać zależnością:

$$
a(R C A)=\left\{\begin{array}{lll}
\frac{\ln (199)}{\ln (R C A)} & \text { dla } & R C A>1 \\
-\frac{\ln (199)}{\ln (R C A)} & \text { dla } & R C A \in(0 ; 1)
\end{array}\right.
$$

W miarę wzrostu wartości wskaźnika (1) poziom parametru a zapewniający zbieżność skorygowanego wskaźnika $R C A$ do górnego kresu zbioru $[-1,1)$ z 1-procentową dokładnością maleje asymptotycznie do 0. Jeśli np. maksymalna wartość wskaźnika względnej przewagi komparatywnej wynosi 200, to konieczne jest przyjęcie wykładnika $a$ równego ok. 1, aby uzyskać zbieżność do górnej granicy przedziału $[-1,1) \mathrm{z}$ wymaganą dokładnością (por. rys. 2).

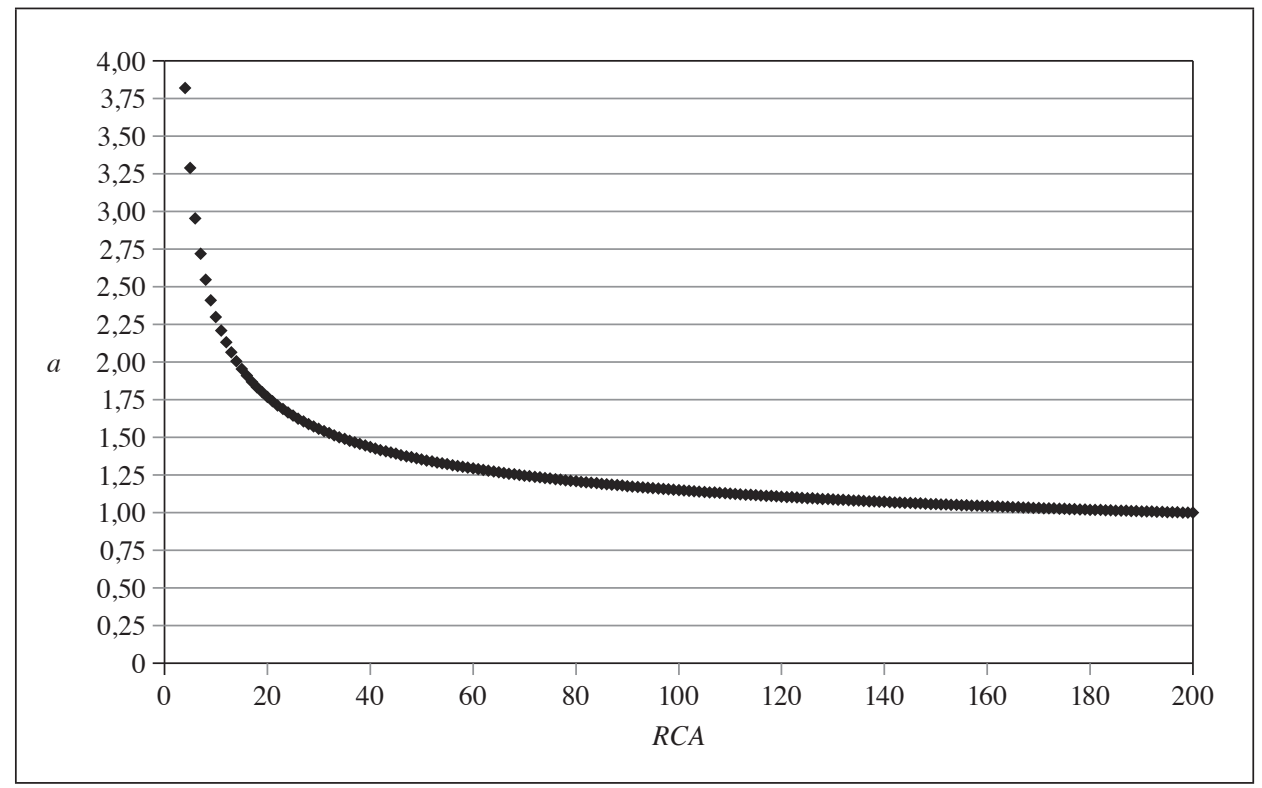

Rys. 2. Wykres funkcji $a(R C A)$ dla $R C A>1$

Źródło: opracowanie własne. 
Należy zauważyć, że przyjęcie zbyt niskiej wartości parametru $a$ (przy ustalonym poziomie wskaźnika $R C A$ ) spowoduje oddolne i odgórne zawężenie obszaru zmienności wskaźnika $R C A_{k}^{a}$.

\section{Ocena stabilności empirycznego rozkładu wartości wskaźnika przewagi komparatywnej w czasie}

Empiryczne rozkłady wskaźnika ujawnionej przewagi komparatywnej analizowano na przykładzie Polski względem Słowacji jako kraju referencyjnego. Do zbadania stabilności empirycznych rozkładów wskaźników $R C A$ i $R C A_{k}^{(a)}$ w czasie zastosowano test zgodności chi-kwadrat dla liczebności obserwowanych względem oczekiwanych (jako oczekiwane liczebności przyjęto rozkłady częstości wskaźnika z poprzednich lat w stosunku do wybranego roku badawczego).

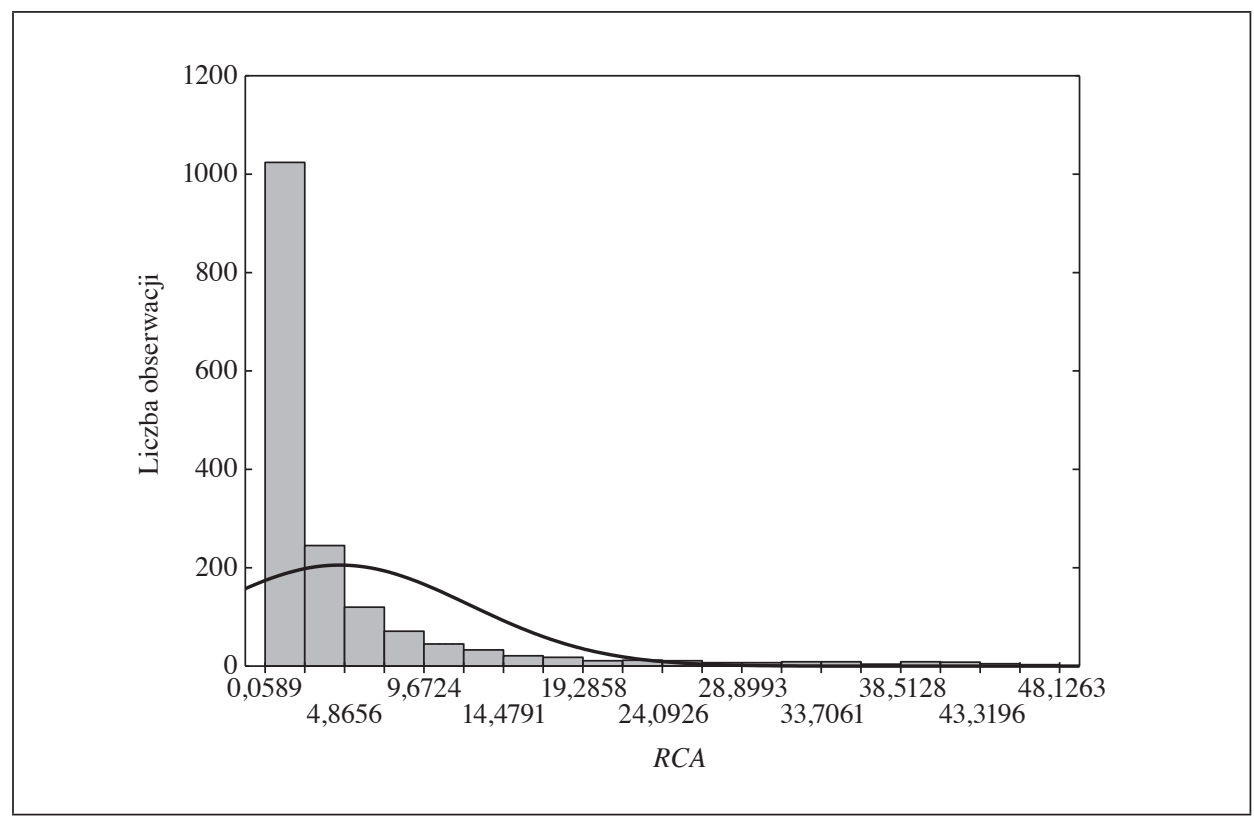

Rys. 3. Rozkład wartości wskaźnika $R C A$ dla Polski względem Słowacji jako kraju referencyjnego w $2005 \mathrm{r}$.

Źródło: opracowanie własne na podstawie danych Eurostatu.

W tym celu wartości wskaźników $R C A$ i $R C A_{k}^{(a)}$ w każdym z lat 2005-2006 zostały pogrupowane $\mathrm{w}$ szeregi rozdzielcze przedziałowe. $\mathrm{W}$ analizie posłużono się szeregami składającymi się z 20 klas, zachowując postulat podziału rozłącz- 
nego i wyczerpującego [Sobczyk 2000]. Z większości przypadków tworzono szeregi o jednakowych interwałach klasowych z wyjątkiem sytuacji występowania obserwacji ekstremalnych - wówczas wprowadzano otwarte skrajne klasy w szeregu statystycznym. Na rys. 3 i 4 przedstawiono przykładowe rozkłady wartości wskaźników $R C A$ i $R C A_{k}^{(a)}$ dla $a=0,2$ obliczone dla Polski względem Słowacji jako kraju referencyjnego w 2005 r. Ze względu na znaczny zakres zmienności wskaźnika $R C A$ na rys. 3 przedstawiono fragment rozkładu jego wartości, pomijając ok. $10 \%$ obserwacji ekstremalnych. Rozkład wartości wskaźnika $R C A$ (rys. 3) cechuje się znaczną asymetrią prawostronną, natomiast wskaźnik $R C A_{k}^{(0,2)}$ (rys. 4) ma kształt rozkładu zbliżony do krzywej Gaussa-Laplace’a.

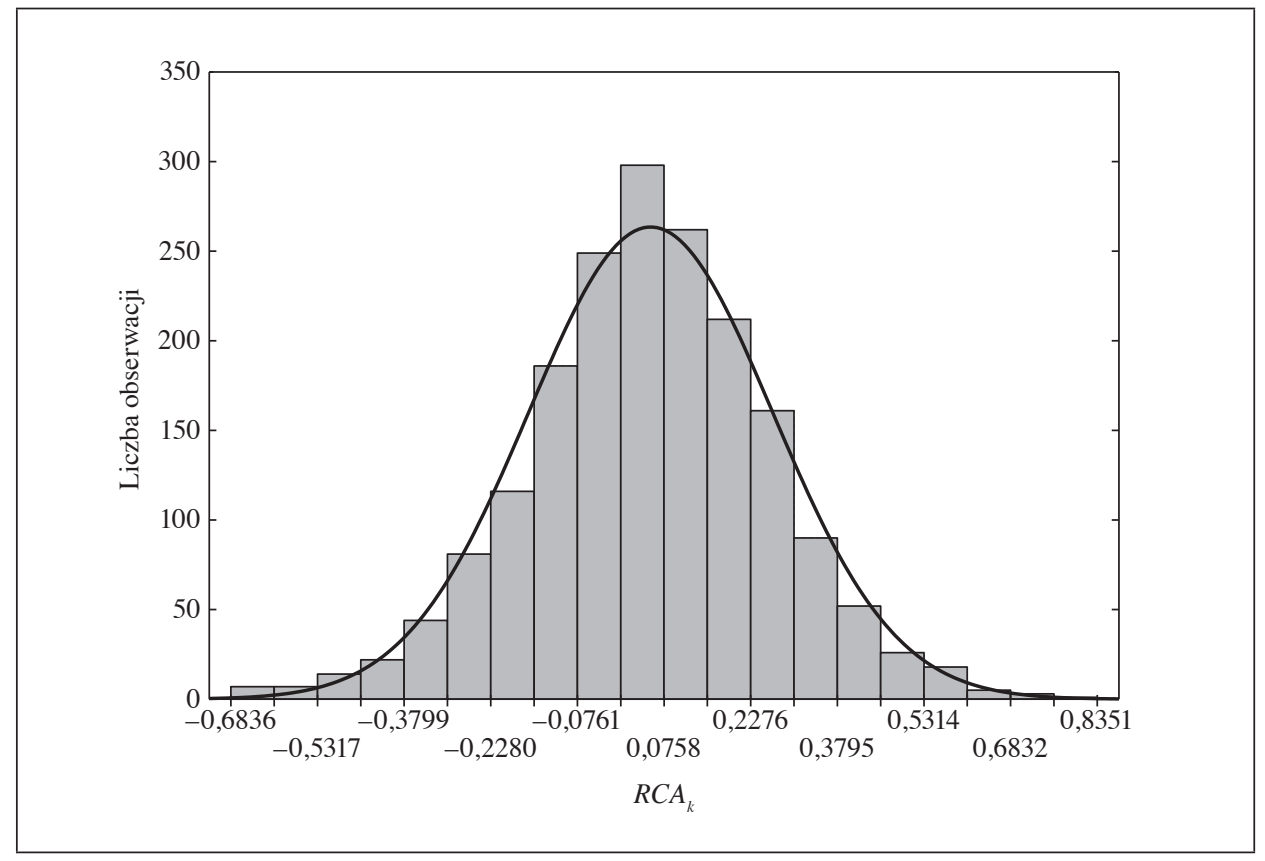

Rys. 4. Rozkład wartości wskaźnika $R C A_{k}^{(0,2)}$ dla Polski względem Słowacji jako kraju referencyjnego w $2005 \mathrm{r}$.

Źródło: opracowanie własne na podstawie danych Eurostatu.

W tabeli 1 przedstawiono wyniki testu chi-kwadrat dla rozkładu wartości wskaźnika $R C A$ obliczonego dla Polski względem Słowacji jako kraju referencyjnego (w nawiasach podano wartości prawdopodobieństw testowych).

Na podstawie wyników w tabeli 1 można stwierdzić, że jedynie dwie wartości testu chi-kwadrat są statystycznie nieistotne i wskazują na stabilność rozkładów empirycznych wskaźnika $R C A$ w następujących okresach: w 2007 r. w porów- 
naniu z 2006 r., a także w 2008 r. w porównaniu z 2007 r. W tabeli 2 przedstawiono wartości statystyki chi-kwadrat dla wskaźników $R C A_{k}^{(1)}, R C A_{k}^{(0,5)}, R C A_{k}^{(0,2)}$ i $R C A_{k}^{(0,1)}$ obliczonych dla Polski względem Słowacji jako kraju referencyjnego.

Tabela 1. Wyniki testu chi-kwadrat dla rozkładu wartości wskaźnika $R C A$ obliczonego w poszczególnych latach 2005-2009 dla Polski względem Słowacji jako kraju referencyjnego

\begin{tabular}{|c|c|c|c|c|}
\hline Lata & 2005 & 2006 & 2007 & 2008 \\
\hline 2006 & $\begin{array}{l}33,356 \\
(0,022)\end{array}$ & - & - & - \\
\hline 2007 & $\begin{array}{l}30,867 \\
(0,042)\end{array}$ & $\begin{array}{l}28,726 \\
(0,070)\end{array}$ & - & - \\
\hline 2008 & $\begin{array}{l}49,646 \\
(0,000)\end{array}$ & $\begin{array}{l}47,000 \\
(0,000)\end{array}$ & $\begin{array}{l}20,958 \\
(0,339)\end{array}$ & - \\
\hline 2009 & $\begin{array}{l}41,401 \\
(0,002)\end{array}$ & $\begin{array}{l}44,310 \\
(0,001)\end{array}$ & $\begin{array}{l}49,436 \\
(0,000)\end{array}$ & $\begin{array}{l}37,890 \\
(0,006)\end{array}$ \\
\hline
\end{tabular}

Źródło: opracowanie własne na podstawie danych Eurostatu.

Tabela 2. Wyniki testu chi-kwadrat dla rozkładu wartości wskaźników $R C A_{k}^{(a)}$ obliczonych w latach 2005-2008 dla Polski względem Słowacji jako kraju referencyjnego

\begin{tabular}{|c|c|c|c|c|c|c|c|c|}
\hline Wskaźnik & \multicolumn{4}{|c|}{$R C A_{k}^{(1)}$} & \multicolumn{4}{|c|}{$R C A_{k}^{(0,5)}$} \\
\hline Lata & 2005 & 2006 & 2007 & 2008 & 2005 & 2006 & 2007 & 2008 \\
\hline 2006 & $\begin{array}{l}29,325 \\
(0,061)\end{array}$ & - & - & - & $\begin{array}{l}21,381 \\
(0,316)\end{array}$ & - & - & - \\
\hline 2007 & $\begin{array}{l}28,759 \\
(0,070)\end{array}$ & $\begin{array}{l}19,486 \\
(0,426)\end{array}$ & - & - & $\begin{array}{l}26,912 \\
(0,107)\end{array}$ & $\begin{array}{l}22,000 \\
(0,284)\end{array}$ & - & - \\
\hline 2008 & $\begin{array}{l}37,060 \\
(0,008)\end{array}$ & $\begin{array}{r}19,789 \\
(0,407)\end{array}$ & $\begin{array}{l}28,868 \\
(0,068)\end{array}$ & - & $\begin{array}{l}30,917 \\
(0,041)\end{array}$ & $\begin{array}{l}19,409 \\
(0,431)\end{array}$ & $\begin{array}{l}23,812 \\
(0,203)\end{array}$ & - \\
\hline 2009 & $\begin{array}{r}30,694 \\
(0,044) \\
\end{array}$ & $\begin{array}{r}17,190 \\
(0,577) \\
\end{array}$ & $\begin{array}{l}35,668 \\
(0,012)\end{array}$ & $\begin{array}{l}22,164 \\
(0,276)\end{array}$ & $\begin{array}{r}20,710 \\
(0,353)\end{array}$ & $\begin{array}{l}24,660 \\
(0,172)\end{array}$ & $\begin{array}{l}17,445 \\
(0,560)\end{array}$ & $\begin{array}{l}18,149 \\
(0,513) \\
\end{array}$ \\
\hline Wskaźnik & \multicolumn{4}{|c|}{$R C A_{k}^{(0,2)}$} & \multicolumn{4}{|c|}{$R C A_{k}^{(0,1)}$} \\
\hline Lata & 2005 & 2006 & 2007 & 2008 & 2005 & 2006 & 2007 & 2008 \\
\hline 2006 & $\begin{array}{l}21,381 \\
(0,316)\end{array}$ & - & - & - & $\begin{array}{c}17,818 \\
(0,535)\end{array}$ & - & - & - \\
\hline 2007 & $\begin{array}{c}16,912 \\
(0,596)\end{array}$ & $\begin{array}{l}12,959 \\
(0,841)\end{array}$ & - & - & $\begin{array}{l}17,427 \\
(0,561)\end{array}$ & $\begin{array}{l}13,813 \\
(0,794)\end{array}$ & - & - \\
\hline 2008 & $\begin{array}{l}12,917 \\
(0,843)\end{array}$ & $\begin{array}{l}19,409 \\
(0,431)\end{array}$ & $\begin{array}{l}13,812 \\
(0,795)\end{array}$ & - & $\begin{array}{c}16,764 \\
(0,606)\end{array}$ & $\begin{array}{c}16,174 \\
(0,646)\end{array}$ & $\begin{array}{l}14,843 \\
(0,733)\end{array}$ & - \\
\hline 2009 & $\begin{array}{r}17,710 \\
(0,542)\end{array}$ & $\begin{array}{l}14,660 \\
(0,744)\end{array}$ & $\begin{array}{l}22,445 \\
(0,263)\end{array}$ & $\begin{array}{l}24,149 \\
(0,190)\end{array}$ & $\begin{array}{l}15,758 \\
(0,673)\end{array}$ & $\begin{array}{r}15,550 \\
(0,687)\end{array}$ & $\begin{array}{c}17,038 \\
(0,587)\end{array}$ & $\begin{array}{l}18,124 \\
(0,514)\end{array}$ \\
\hline
\end{tabular}

Źródło: opracowanie własne na podstawie danych Eurostatu. 
Liczba statystycznie nieistotnych wyników testu chi-kwadrat świadczących o stabilności rozkładu wskaźnika $R C A_{k}^{(a)}$ w poszczególnych latach wzrasta wraz ze zmniejszaniem wartości parametru $a$. W przypadku $a=1$ można stwierdzić 7 wartości statystycznie nieistotnych (na 10 wyników), dla $a=0,5$ zaobserwowano 9 wyników statystycznie nieistotnych, natomiast dla $a=0,2$ bądź $a=0,1$ żaden z wyników testu nie był statystycznie istotny.

Z przeprowadzonych obliczeń wynika, że zaproponowany wskaźnik $R C A_{k}^{(a)}$ cechuje się znacznie wyższym poziomem stabilności w czasie niż klasyczny wskaźnik $R C A$.

\section{Ocena stabilności empirycznego rozkładu wartości wskaźnika przewagi komparatywnej względem grup towarowych}

Celem dalszej analizy jest porównanie empirycznych rozkładów wartości wskaźników $R C A$ i $R C A_{k}^{(a)}$ w wybranych grupach towarowych zgodnych z nomenklaturą międzynarodowej standardowej klasyfikacji handlu (standard international trade classification - SITC) oraz ocena wrażliwości wartości charakterystyk liczbowych tych rozkładów względem grup towarowych. W badaniach wzięto pod uwagę grupy towarowe o dostatecznie dużej liczbie obserwacji - wskaźników względnej przewagi komparatywnej obliczonych dla podgrup towarowych wyróżnionych na pięciocyfrowym poziome dezagregacji. Ostatecznie w badaniach uwzględniono 5 grup towarowych zawierających co najmniej 300 obserwacji:

- SITC 0 - żywność i żywe zwierzęta,

- SITC 5 - chemikalia i produkty pokrewne,

- SITC 6 - artykuły przemysłowe klasyfikowane według materiałów,

- SITC 7 - maszyny, urządzenia i środki transportu,

- SITC 8 - inne wyroby przemysłowe.

Przed wykonaniem analizy ze zbioru obliczonych wskaźników przewagi komparatywnej usunięto obserwacje odstające, które mogły zniekształcać opis rozkładu wskaźnika. W ramach każdej grupy towarowej SITC wyeliminowano $10 \%$ wartości ekstremalnych.

W tabelach 3 i 4 przedstawiono wybrane charakterystyki liczbowe w rozkładzie wartości wskaźników $R C A$ i $R C A_{k}^{(a)}$ dla $a=0,5$, obliczone dla Polski względem Słowacji jako kraju odniesienia.

Średnie wartości wskaźnika $R C A$, jak również wartości median przedstawione w tabeli 3 we wszystkich rozważanych grupach towarowych SITC są większe od jedności. Wynika z tego, że Polska posiada przewagę komparatywną w eksporcie względem Słowacji we wszystkich rozważanych grupach towarowych SITC. To spostrzeżenie znajduje również potwierdzenie w wynikach przedstawionych 
w tabeli 4 - przeciętne wartości wskaźnika $R C A_{k}^{(0,5)}$ są większe od 0 we wszystkich grupach towarowych. Wartości współczynników asymetrii zawarte w tabeli 4 pokazują również, iż asymetria w rozkładach wskaźnika $R C A_{k}^{(0,5)}$ w poszczególnych grupach towarowych SITC jest zazwyczaj słaba i lewostronna, podczas gdy asymetria w rozkładach wskaźnika $R C A$ jest zwykle silna i prawostronna (por. tabela 3).

Tabela 3. Wybrane charakterystyki rozkładu wartości wskaźnika $R C A$ obliczonego według grup towarowych SITC dla Polski względem Słowacji jako kraju referencyjnego w $2009 \mathrm{r}$.

\begin{tabular}{|l|c|c|c|c|c|}
\hline Charakterystyka liczbowa & SITC 0 & SITC 5 & SITC 6 & SITC 7 & SITC 8 \\
\hline Średnia & 4,791 & 4,763 & 3,754 & 2,733 & 2,439 \\
\hline Mediana & 2,984 & 2,252 & 1,563 & 1,074 & 1,415 \\
\hline Minimum & 0,443 & 0,07 & 0,074 & 0,079 & 0,142 \\
\hline Maksimum & 24,989 & 22,698 & 34,414 & 21,464 & 13,081 \\
\hline Kwartyl dolny & 1,216 & 0,69 & 0,539 & 0,477 & 0,583 \\
\hline Kwartyl górny & 6,459 & 6,275 & 4,297 & 3,271 & 3,032 \\
\hline Odchylenie standardowe & 5,058 & 5,746 & 5,491 & 3,819 & 2,707 \\
\hline Współczynnik asymetrii & 1,92 & 1,568 & 2,73 & 2,425 & 1,877 \\
\hline
\end{tabular}

Źródło: opracowanie własne na podstawie danych Eurostatu.

Tabela 4. Wybrane charakterystyki rozkładu wartości wskaźnika $R C A_{k}^{(0,5)}$ obliczonego według grup towarowych SITC dla Polski względem Słowacji jako kraju referencyjnego w 2009 r.

\begin{tabular}{|l|c|c|c|c|c|}
\hline Charakterystyka liczbowa & SITC 0 & SITC 5 & SITC 6 & SITC 7 & SITC 8 \\
\hline Średnia & 0,241 & 0,162 & 0,097 & 0,105 & 0,074 \\
\hline Mediana & 0,267 & 0,2 & 0,111 & 0,018 & 0,086 \\
\hline Minimum & $-0,201$ & $-0,581$ & $-0,571$ & $-0,56$ & $-0,452$ \\
\hline Maksimum & 0,667 & 0,653 & 0,709 & 0,911 & 0,567 \\
\hline Kwartyl dolny & 0,049 & $-0,093$ & $-0,153$ & $-0,183$ & $-0,134$ \\
\hline Kwartyl górny & 0,435 & 0,429 & 0,349 & 0,288 & 0,27 \\
\hline Odchylenie standardowe & 0,239 & 0,331 & 0,323 & 0,399 & 0,264 \\
\hline Współczynnik asymetrii & $-0,150$ & $-0,397$ & $-0,157$ & 0,527 & $-0,095$ \\
\hline
\end{tabular}

Źródło: opracowanie własne na podstawie danych Eurostatu.

Aby zbadać, który wskaźnik względnej przewagi komparatywnej generuje rozkłady bardziej wrażliwe na rodzaj grupy towarowej, przeprowadzono testy zgodności rozkładów wskaźników $R C A$ i $R C A_{k}^{(0,5)}$ dla wszystkich par rozważanych 
grup towarowych zgodnych z nomenklaturą SITC. Wyniki testów przedstawiono w tabelach 5 i 6 .

Tabela 5. Wyniki testu chi-kwadrat dla rozkładu wartości wskaźnika $R C A$ obliczonego w poszczególnych grupach towarowych SITC dla Polski względem Słowacji jako kraju referencyjnego

\begin{tabular}{|c|c|c|c|c|}
\hline Grupa towarowa & SITC 5 & SITC 6 & SITC 7 & SITC 8 \\
\hline \multirow{2}{*}{ SITC 0 } & 50,097 & 10,235 & 24,867 & 86,956 \\
& $(0,000)$ & $(0,947)$ & $(0,165)$ & $(0,000)$ \\
\hline \multirow{2}{*}{ SITC 5 } & - & 51,338 & 39,277 & 112,001 \\
& - & $(0,000)$ & $(0,004)$ & $(0,000)$ \\
\hline \multirow{2}{*}{ SITC 6 } & - & - & 41,866 & 89,728 \\
& - & - & $(0,002)$ & $(0,000)$ \\
\hline \multirow{2}{*}{ SITC 7 } & - & - & 113,929 \\
& & & & $(0,000)$ \\
\hline
\end{tabular}

Źródło: opracowanie własne na podstawie danych Eurostatu.

Tabela 6 . Wyniki testu chi-kwadrat dla rozkładu wartości wskaźnika $R C A_{k}^{(0,5)}$ obliczonego w poszczególnych grupach towarowych SITC dla Polski względem Słowacji jako kraju referencyjnego

\begin{tabular}{|c|c|c|c|c|}
\hline Grupa towarowa & SITC 5 & SITC 6 & SITC 7 & SITC 8 \\
\hline \multirow{2}{*}{ SITC 0 } & 22,24 & 14,998 & 23,101 & 18,244 \\
& $(0,272)$ & $(0,723)$ & $(0,233)$ & $(0,506)$ \\
\hline \multirow{2}{*}{ SITC 5 } & - & 7,04 & 15,965 & 23,1444 \\
& - & $(0,994)$ & $(0,660)$ & $(0,231)$ \\
\hline \multirow{2}{*}{ SITC 6 } & - & - & 11,54 & 15,828 \\
& - & - & - & $(0,904)$ \\
\hline \multirow{2}{*}{ SITC 7 } & - & - & $56,669)$ \\
& & - & & $(0,000)$ \\
\hline
\end{tabular}

Źródło: opracowanie własne na podstawie danych Eurostatu.

W tabeli 5 przedstawiającej wyniki testu chi-kwadrat dla rozkładów wskaźnika $R C A$ znajdują się 2 wartości statystycznie nieistotne, natomiast w tabeli 6 zawierającej wyniki testu chi-kwadrat dla rozkładu wartości wskaźnika $R C A_{k}^{(0,5)}$ jest 9 nieistotnych wartości testu. Na podstawie otrzymanych rezultatów badań można przypuszczać, że rozkłady wartości wskaźnika $R C A_{k}^{(a)}$ w poszczególnych grupach SITC są bardziej stabilne niż w przypadku rozkładów wskaźnika $R C A$. Można zatem sądzić, że rozkład wartości wskaźnika $R C A_{k}^{(a)}$ jest mniej wrażliwy na wybór grupy towarowej SITC w porównaniu z wartościami wskaźnika $R C A$. Dodatkowe badania pokazały, że stabilność rozkładów wartości wskaźników $R C A_{k}^{(a)}$ jest tym wyższa, im niższy jest poziom parametru $a$. 


\section{Podsumowanie}

Zaproponowana modyfikacja popularnego wskaźnika ujawnionej względnej przewagi komparatywnej wydaje się do pewnego stopnia eliminować jego wady. Znajduje to potwierdzenie w przedstawionych własnościach wskaźnika $R C A_{k}^{(a)}$ oraz w wynikach badań empirycznych przeprowadzonych na przykładzie Polski i Słowacji jako kraju referencyjnego. Przede wszystkim wartości skorygowanego wskaźnika $R C A$ są unormowane w przedziale $[-1,1)$, co umożliwia ich łatwą interpretację. Wartości miernika $R C A_{k}^{(a)}$ generują rozkłady znacznie bardziej symetryczne niż w przypadku rozkładów wskaźnika $R C A$. Rozkłady te są również bardziej stabilne w czasie i mniej wrażliwe na rodzaj grupy towarowej. Ułatwia to porównywalność poziomów ujawnionej przewagi komparatywnej w ujęciu czasowym i towarowym. Z kolei za widoczny mankament miernika $R C A_{k}^{(a)}$ należy uznać jego tendencję do silnego zawężenia zakresu swoich wartości przy bliskim zeru poziomie parametru $a$. Niemniej przez optymalny dobór wartości $a$ zależny od zakresu zmienności oryginalnego wskaźnika $R C A$ można uzyskać pożądane tempo zbieżności wskaźnika $R C A_{k}^{(a)}$ do wartości granicznych przedziału $[-1,1)$.

\section{Literatura}

Balassa B. [1965], Trade Liberalisation and 'Revealed' Comparative Advantage, „Manchester School of Economics and Social Studies", vol. 33.

Dalum B., Laursen K., Villumsen G. [1998], Structural Change in OECD Export Specialization Patterns: Despecialization and 'Stickiness', ,International Review of Applied Economics", vol. 12(3).

Hoen A.R., Oosterhaven J. [2006], On the Measurement of Comparative Advantage, „The Annals of Regional Science", vol. 40(3).

Iapadre P.L. [2001], Measuring International Specialization, „International Advances in Economic Research", vol. 7(2).

Misala J. [2011], Międzynarodowa konkurencyjność gospodarki narodowej, PWE, Warszawa.

Ricardo D. [1957], Zasady ekonomii politycznej i opodatkowania, PWE, Warszawa.

Sobczyk M. [2000], Statystyka. Podstawy teoretyczne, przykłady, zadania, Wydawnictwo Uniwersytetu Marii Curie-Skłodowskiej, Lublin.

Yu R., Cai J., Leung P. [2000], The Normalized Revealed Comparative Advantage Index, „The Annals of Regional Science”, vol. 43(1). 


\section{A Proposal to Modify the Revealed Comparative Index with the Application of Rational Functions}

The Revealed Comparative Advantage Index (RCA) is used to estimate the export attractiveness and comparative advantage in the country by industry sectors or commodity groups. This measure has many disadvantages because it ranges from 0 to $\infty$.

Its empirical distribution is strongly asymmetric and is not stable in time. The Revealed Comparative Advantage Index distribution is strongly dependent on the number of reference countries, industries and commodity groups taken under consideration. In consequence, some RCA distribution parameters are not stable. These problematic properties make its outcomes impossible to compare across time and space.

The paper proposes transforming the RCA measure into a new index, ranging from -1 to 1 , by using a special class of rational functions. The new measure has a symmetric distribution with a stable mean and is independent of the industry sectors or commodity groups. Empirical distributions of the adjusted RCA index are built on the basis of data on Polish export and import commodities by Standard International Trade Classification (SITC).

Keywords: Revealed Comparative Advantage Index, export, stable distribution, chi-square test. 